\title{
Roger Owen - Eminent Scientist and Extraordinary Friend
}

\author{
Pavao Marović, Mirela Galić \\ Faculty of Civil Engineering, Architecture and Geodesy, University of Split, Matice hrvatske 15, HR-21000 Split, CROATIA \\ e-mails:, marovic@gradst.hr, mirela.galic@gradst.hr
}

\section{SUMMARY}

With profound sadness we heard that Professor Roger Owen passed away on Monday $13^{\text {th }}$ January 2020. He was eminent scientist, researcher, lecturer, teacher, mentor, engineer, and above all beloved husband and father, good man and reliable, altruistic, genial and extraordinary friend. With this review we want to describe, after conventional curriculum vitae, his connections with researchers and professors from the University of Split, Faculty of Civil Engineering, Architecture and Geodesy, as well as some common projects.

KEY WORDS: $\quad$ Roger Owen; Swansea; Engineering Computations; computational mechanics; plasticity; finite element method; discrete element method.

\section{INTRODUCTION}

Professor David Roger Jones Owen beloved husband of Janet, devoted father of Kathryn and Lisa, and loving Grandpa to Bethan, extraordinary friend to many, eminent scholar and scientist passed away peacefully on January 13, 2020.

This article is dedicated to the memory of Prof. Roger Owen. In Section 2 we will present Prof. Owen's curriculum vitae incorporating his research profile, leadership contributions, awards and distinctions, named lectures and entrepreneurship. In Section 3 we will describe some common projects with colleagues from University of Split, especially from the Faculty of Civil Engineering, Architecture and Geodesy, and their reminiscences. In Section 4 we will specify some details of the awarding ceremony of Honorary Doctorate at the University of Split. Some general information has been taken from [1-4].

\section{ROGER OWEN - CURRICULUM VITAE}

Professor David Roger Jones Owen was born on 27 May 1942 in small village of Bynea close to Llanelli, Wales, United Kingdom, in a steelworker family. He adopted early education at Llanelli Grammar School and graduated at University College of Swansea of the University of Wales (now Swansea University), in 1963 with B.Sc. and in 1964 with M.Sc. degrees. He completed his Ph.D. in 1967 at Northwestern University, Evanston, Illinois, United States of America, 
under the guidance of Prof. Toshio Mura, in the field of Theoretical and Applied Mechanics [5]. This work, and also his early post-doctoral experience as a Walter P. Murphy Research Fellow at Northwestern, involved both the analytical and computational study of fundamental plastic material deformation described by continuously distributed dislocation mechanisms. Except for his doctoral and postdoctoral studies, he spent his entire career at the Swansea University in Swansea, Wales. Namely, he subsequently returned to University College of Swansea of the University of Wales (now Swansea University) to take up an academic post in the Department of Civil Engineering (now Zienkiewicz Centre for Computational Engineering, as part of the College of Engineering), where under the influence of Prof. Olgierd C. Zienkiewicz, he developed an interest in computational methods.
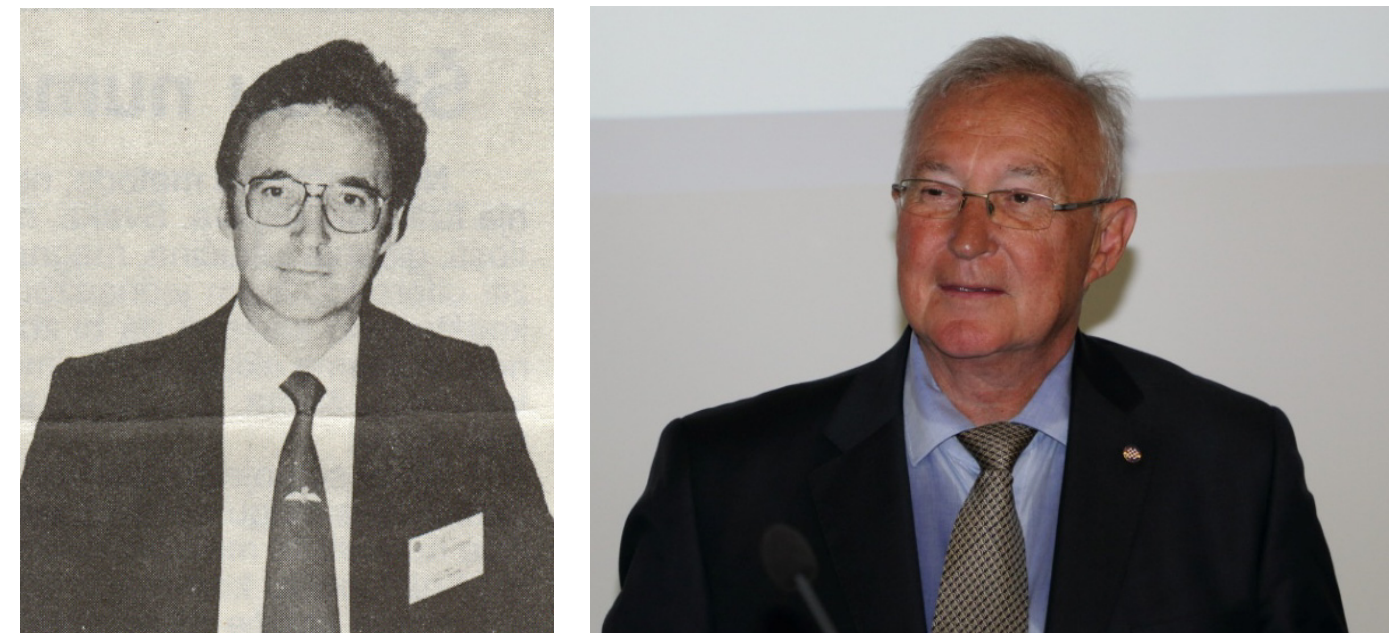

Photo 1 Professor Roger Owen: First visit to Split, ICC Conference, 1984 (left) and last visit to Split, Honorary Doctorate, 2016 (right)

Professor Roger Owen [1] was one of the few extraordinary cases in which the same person gathers all the attributes of being an eminent scientist and academic, and by having contributed with their work to the development of society. As a scientist he made important contributions to the field of computational mechanics, in particular, he was an international authority on finite element and discrete element techniques. He was also a fine academic, an excellent teacher and a mentor of over $80 \mathrm{Ph}$.D. students. Last but not least, his work has been seminal to the development of computational mechanics worldwide.

As an international authority on finite element and discrete element techniques, Prof. Owen is the author of seven textbooks [6-12] and over four hundred scientific publications. In addition to being the editor of over thirty monographs and conference proceedings, he was the founder (in 1984) and the editor (for 36 years) of the International Journal for Engineering Computations and was a member of many Editorial Boards. His journal (International Journal for Engineering Computations) was encouragement to us to establish our journal, International Journal for Engineering Modelling, in 1989.

\subsection{RESEARCH PROFILE}

As mentioned before, Prof. Owen's early research, in the field of solid and structural mechanics, has centred on the development of solution procedures for non-linear problems encountered in science and engineering. At Northwestern University he performed his 
research in the field of theoretical and applied mechanics, especially in both the analytical and computational study of fundamental plastic material deformations described by continuous distributed dislocation mechanisms. After returning to University College of Swansea of the University of Wales (now Swansea University), under the influence of Prof. Zienkiewicz, he developed an interest in computational methods. From that time, Prof. Owen has contributed prominently to the development of computational strategies for plastic deformation problems, both for fundamental material studies and for application to engineering structures and components.

Over the last two decades, Prof. Owen's work has focused on the development of discrete element methods for particulate modelling and the simulation of multi-fracturing phenomena in materials, where much of his research has been pioneering. This work has extended developments in the continuum modelling of finitely deforming solids by including damage/fracture based failure and introducing material separation on a local basis to permit simulation of the degradation of a continuum into a multi-fractured particulate state. Based upon this methodology, contributions have been made to fundamental understanding in several key application areas; including explosive simulations which necessitates coupling of the multi-fracturing solid behaviour with the evolving detonation gas distribution, deep level mining/oil recovery operations, defence problems related to high velocity impact involving penetration of metallic and ceramic materials and structural failure predictions for impact, seismic and blast loading.

With an interest in solving large-scale problems, Prof. Owen has over the last three decades been engaged in the development of parallel processing strategies for the simulation of engineering and scientific problems. Commencing from early work on shared memory machines, his most recent work has involved implementation on distributed memory platforms, where for problems involving multi-fracturing solids or adaptive mesh refinement in which continual changes in mesh topology takes place, the development of dynamic domain partitioning schemes and incremental inter-processor data migration is essential.

More recently, Prof. Owen has become involved in research for describing random media fields in stochastic finite element modelling with a view to modelling both uncertainties in the distribution of material properties and the presence of internal fractures in geomechanical and other solids. A further topic of recent research has been the coupling of particulate systems and multi-fracturing solids with other physical fields, involving liquids or gases, through the introduction of a Lattice Boltzmann description.

The extensive practical content of his scientific publications permitted readers to develop computational solutions and methods of their own for a wide range of academic and industrial problems. These developments can be recognized in many codes found in commercial systems worldwide.

Among many initiatives, Prof. Owen participated in the establishment of two significant series of International Conferences, namely Computer Aided Analysis and Design of Concrete Structures (now known under the name EURO-C) since 1984 and Computational Plasticity where he was co-chair and editor of 15 conferences held in Barcelona since 1987.

\subsection{LEADERSHIP CONTRIBUTIONS}

Professor Owen played a leading role in national and international scientific affairs. For example, he was a member of the Executive Council of IACM (International Association for 
Computational Mechanics) which is a worldwide organisation established to promote and guide research and applications in the field of numerical modelling. He was a Board Member of the European Council for Computational Mechanics (ECCM) and was also Past Chairman of the UK Association for Computational Mechanics in Engineering, which is the national association affiliated to IACM. A further measure of Prof. Owen's research esteem was his membership of the Research Assessment Exercise panel for Civil Engineering in 2001. He has been appointed to similar panels for the corresponding exercise in Mechanical Engineering for the Netherlands (QANU Quality Assurance Netherlands Universities) in 2000 and 2008 and DeutscheForschungsGemeinschaft (DFG), Germany in 2006 and 2007 for its Graduate Schools, Centres of Excellence and Institutional Funding initiatives. In 2012 he was appointed to the review panel for the Engineering Graduate Schools in the Netherlands and was Chair of the Scientific Advisory Panel for the 5-year review of the International Centre for Numerical Methods in Engineering (CIMNE) in Barcelona. He was also a member of the International Advisory Board for the Institute for High Performance Computing in Singapore for a five year period. Due to his industrial involvement, Prof. Owen served for over ten years as elected Council Member of NAFEMS, which is an international organisation aimed at establishing standards and quality assurance procedures for the safe use of finite element methods. Professor Owen was a member of the Civil Engineering Panel for the United Kingdom Research Excellence Framework (REF) exercise undertaken in 2014 and also a member of the International Peer Review Panel of the College of Engineering, Peking University in 2014. He was also a Council Member of the Royal Society and a Council Member of the Learned Society of Wales.

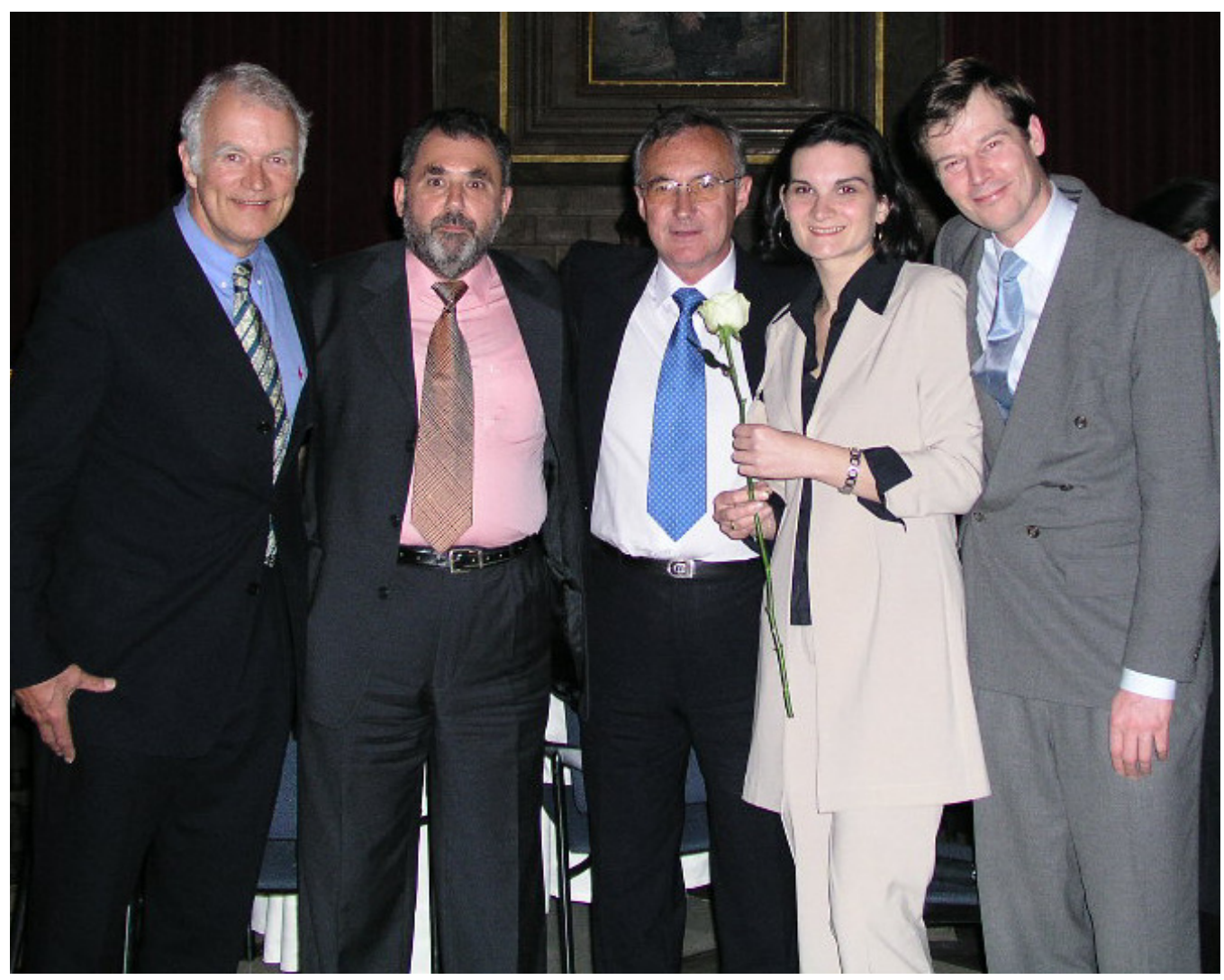

Photo 2 At the COMPLAS VII Conference in Barcelona, Banquet at the Palau de la Generalitat de Catalunya, April 9, 2003 (from left: dr. Paul Lyons (from LUSAS), prof. Pavao Marović, prof. Roger Owen, prof. Mirela Galić, prof. Rene de Borst) 


\subsection{AWARDS AND DISTINCTIONS}

Professor Owen's profound contributions to research, especially to the field of computational mechanics and modelling, has been recognized by many institutions, universities and organizations, and the most distinguishable are listed here:

$>$ Elected Fellow of the Royal Academy of Engineering, London, United Kingdom, in 1996.

> Awarded an Honorary Doctorate by the University of Porto, Porto, Portugal, in 1998.

$>$ Received the Computational Mechanics Award of the International Association for Computational Mechanics (IACM), in 2002, for "outstanding contributions in the field of computational mechanics".

$>$ Awarded the Warner T. Koiter Medal of the American Society of Mechanical Engineers (ASME), in 2003, for "contributions to the field of theoretical and computational solid mechanics".

$>$ Awarded the Gauss-Newton Medal of the International Association for Computational Mechanics (IACM), in 2004, for "outstanding contributions in the field of computational mechanics".

$>$ Awarded the Gold Medal of the University of Split, Split, Croatia, in 2004, for "international achievements in the field of computational mechanics".

$>$ Awarded the Premium Medal of the Spanish Society for Computational Mechanics (SEMNI), Barcelona, Spain, in 2005, for "recognition of his outstanding scientific work".

$>$ Awarded an Honorary Doctorate by Ecole Normale Superieure de Cachan, France, in 2007.

$>$ Elected Fellow of the Royal Society, London, United Kingdom, in 2009.

$>$ Honorary Professor, Wales Institute for Mathematical and Computational Science, Swansea, Wales, United Kingdom, in 2009.

$>$ Founding Fellow of the Learned Society of Wales, Cardiff, Wales, United Kingdom, in 2009.

$>$ Outstanding Research Activity Award, Swansea University, Swansea, Wales, United Kingdom, in 2009.

$>$ Awarded the Grand Prize of the Japan Society for Computational Engineering and Science (JSCES), Tokyo, Japan, in 2009.

$>$ Elected Honorary Member of Croatian Society of Mechanics (CSM), Zagreb, Croatia, in 2009.

$>$ Elected Foreign Member of the United States National Academy of Engineering (NAE), Washington, United States of America, in 2011.

$>$ Elected Foreign Member of the Chinese Academy of Sciences (CAS), Beijing, China, in 2011.

$>$ Awarded an Honorary Doctorate by Polytechnic University of Catalunya (UPC), Barcelona, Spain, in 2012.

D Elected Council Member of the Royal Society, London, United Kingdom, in 2012.

$>$ Elected Council Member of the Learned Society of Wales, Cardiff, Wales, United Kingdom, in 2012.

$>$ Elected Honorary Professor of China Agricultural University, Beijing, China, in 2014.

$>$ Awarded an Honorary Doctorate by University of Split, Split, Croatia, 2016.

$>$ Awarded an Honorary Doctorate by Swansea University in Swansea, Wales, United Kingdom, in 2016.

$>$ Awarded a Friendship Medal of the People's Republic of China (the highest Chinese award for foreign experts who have made outstanding contributions to the country's economic and social progress), Beijing, China, in 2016.

$>$ Awarded an Honorary Doctorate by University of Cape Town, Cape Town, South Africa, in 2019. 


\subsection{NAMED LECTURES}

Professor Owen has been invited to deliver the following named lectures:

$>$ Prestige Lecture of the Institution of Civil Engineers and the Royal Academy of Engineering, Institution of Civil Engineers, London, United Kingdom, November 2002.

$>$ Warner T Koiter Lecture of the American Society of Mechanical Engineers, Washington, D.C., United States of America, November 2003.

> Alan Jennings Memorial Lecture, Queen's University, Belfast, North Ireland, United Kingdom, April 2007.

> Higginson Lecture, Durham University, England, United Kingdom, November 2011.

$>$ Koiter Lecture, Netherlands Graduate School on Computational Mechanics, Eindhoven, The Netherlands, November 2012.

> Zienkiewicz Memorial Lecture, Livingstone, Zambia, July 2013.

In addition, Prof. Owen has presented over 100 Keynote and Plenary Lectures at leading international conferences in the field of computational mechanics.

Lectures presented at the conferences and notable occasions organized in Croatia by his colleagues from University of Split are listed here:

$>$ Developments in computational procedures for the simulation of industrial forming problems, Invited Lecture, $1^{\text {st }}$ Congress of Croatian Society of Mechanics, Pula, September 15, 1994.

$>$ Recent advances in the field of numerical modelling of engineering structures at the University College of Wales, University of Split, Faculty of Civil Engineering, Split, February 14, 1997. (in cooperation with British Council ALIS Project)

$>$ Assessment and repair evaluation of masonry structures by the discrete element method, Invited Lecture, $2^{\text {nd }}$ Congress of Croatian Society of Mechanics, Supetar, September 19, 1997. (in cooperation with British Council ALIS Project mutual lecture was given by Dr. Nikica Petrinić)

$>$ Actual trends in the development and application of the numerical methods in the analysis of engineering structures, University of Split, Faculty of Civil Engineering, Split, March 25, 1999. (in cooperation with British Council ALIS Project)

$>$ Recent advances in the computational mechanics, University of Split, Faculty of Civil Engineering, Split, March 20, 2001. (in cooperation with British Council ALIS Project mutual lecture given by Eduardo de Souza Neto)

$>$ Recent advances in the computational mechanics: State-of-the-art and future trends, University of Split, Faculty of Civil Engineering, Split, March 20, 2002. (in cooperation with British Council ALIS Project)

$>$ State-of-the art and future trends in the field of the computational mechanics, University of Split, Faculty of Civil Engineering, Split, November 05, 2002.

$>$ State-of-the-art report in computational mechanics, University of Split, Faculty of Civil Engineering and Architecture, Split, December 07, 2004.

$>$ Computational strategies for some coupled problems involving particulate media and multi-fracturing solids, Plenary Lecture, $6^{\text {th }}$ International Congress of Croatian Society of Mechanics, Dubrovnik, October 02, 2009.

$>$ The finite element method: Historical perspective and future prospects, University of Split, Faculty of Civil Engineering, Architecture and Geodesy, Split, June 16, 2016. 


\subsection{ENTREPRENEURSHIP}

In 1985, Prof. Owen formed Rockfield Software Ltd. in 1985, together with Prof. Cedric Taylor and Prof. Kenneth Board, all three professors from University College of Swansea (now Swansea University), aimed at disseminating his academic research based on computational modelling procedures to the industrial sector. The company, initially employing two engineers, was based in the Innovation Centre at the University Campus. Over subsequent years Rockfield Software has expanded to over 30 personnel, with over two thirds of the staff possessing Ph.D. degrees, making the company a leading employer of high technology graduates in the Swansea area.

The success of the company lead to relocation firstly to Technium in the SA1 Development Area in Swansea, followed by a permanent move to the Ethos Building, also in SA1, which it was instrumental in designing and building together with Rowland Jones \& Partners.

Rockfield has a wide portfolio of clients and operates in several commercial areas. Principal sectors in which the company is involved include:

- Failure prediction for structures under seismic or blast loading.

- Industrial forming processes for glass, plastics and metals.

- Food technology processes.

- Defence applications involving explosive and impact conditions.

- Deep level mining and other minerals recovery operations.

- Oil recovery operations and resource prediction.

In addition to both UK and overseas SMEs, Rockfield has over the years built strong relationships with many of the world's leading companies including: Unilever, DSTL, Qinetiq, Corus, Proctor \& Gamble, Devonport Marine Ltd., Rio Tinto, BP-Amaco, Shell, Exxon Mobil, Eni, Chevron, Total-Fina-Elf, Marathon Oil, Miningtek, Orica, Anhauser Busch and Los Alamos, Sandia and Lawrence Livermore National Laboratories. The prominent involvement of Rockfield in the mining and minerals recovery sector lead to the formation of Rockfield Technologies Australia, based in Townsville, Queensland, to support these activities and the company currently employs eight R\&D engineers. In 2016 Rockfield opened their Houston office under the name Rockfield Americas LLC, Houston, Texas, United States of America.

The success of the company has lead, under Prof. Owen's Chairmanship, to the granting of the Queen's Award for Innovation on two separate occasions:

- In 2002 Rockfield received the Queen's Award for the development of finite element/discrete element simulation techniques for the strengthening of masonry bridges and arches. This technology has been utilized within a consortium that includes Cintec International and Gifford \& Partners, to provide a complete service from assessing the need for strengthening, determination through the FE/DE approach of the precise location for insertion of retrofitted reinforcement anchors, to the clean and efficient installation of anchors.

- In 2007 the Queen's Award was granted for outstanding innovation in the development of the ELFEN computational system for the simulation of multi-fracturing solids. Recognition was given to the versatility and widespread industrial application of the methodology in diverse areas such as blast and impact loading of structures, defence applications, mining and minerals operations and oil recovery processes.

Since founding Rockfield Software, Prof. Owen was firstly its Managing Director, and then became Chairman until his retirement from the company in 2010. 


\section{SOME COMMON PROJECTS WITH COLLEAGUES FROM UNIVERSITY OF SPLIT}

Very fruitful collaboration with Prof. Owen started in 1979 when late Prof. Frano B. Damjanić, at that time research assistant at the Faculty of Civil Engineering of the University of Split, had to go on his doctoral studies at University College of Swansea of the University of Wales (now Swansea University). Namely, Frano Damjanić with support of Prof. Vicko Šimić and late Prof. Zlatko Kostrenčić, who was a friend of Prof. Olgierd C. Zienkiewicz, had to go on his doctoral studies in the class of Prof. Zienkiewicz. As Prof. Zienkiewicz could not take him in his group, Prof. Owen became his mentor. At that time at their doctoral and postdoctoral studies were late Prof. Nenad Bićanić, late Prof. Davorin Kovačić and late Ramiz Fejzo, all from Faculty of Civil Engineering of the University of Zagreb.

As Prof. Owen and Damjanić were almost of the same age, they outgrew professor-student relationship and established not only academic, professional and interest relationship, but very close effusive friendship.

Prof. Damjanić altruistically share his knowledge from Swansea with his colleagues and young researches in Split resulting in few M.Sc. (Jure Radnić, Marko Smoljanović, Branimir Jaramaz, Vedrana Kozulić, Srđan Šimunović, Vladica Herak Marović, Mirela Galić) and Ph.D. theses in Split (Pavao Marović, Jure Radnić, Željana Nikolić, Alen Harapin, Mirela Galić). So, the collaboration between Swansea and Split fruitfully started. With Prof. Damjanić's support and recommendation, Ante Munjiza and Miroslav Schoenauer went on their Ph.D. studies to Swansea under the guidance of Prof. Owen, where already there were from University of Zagreb Faculty of Civil Engineering Ph.D. students Đorđe Perić, Nikica Petrinić and Berislav Kralj.

\subsection{ICC-1984 SPLIT}

In his Ph.D. Thesis Frano Damjanić investigated failure behaviour of concrete under both static and transient conditions [13]. That inspirited Prof. Owen, Prof. Ernest Hinton and Prof. Frano Damjanić to organize the International Conference on Computer Aided Analysis and Design of Concrete Structures (ICC). Namely, Prof. Owen had a great knowledge on numerical methods, finite element method and non-linear analyses and less on practical issues on concrete and concrete structures, while Prof. Damjanić, who was a few years older, had great knowledge of concrete and concrete structures because before his Ph.D. in Swansea he had worked in a construction company. So, they launch one idea to organize one great international conference which would couple theoretical and practical knowledge in the field of concrete and concrete structures especially with new methods of design and analysis of concrete structures.

The conference took place in Split, in September 17-21, 1984, and Pavao Marović was technical secretary of the Organizing Committee. The Conference was attended by about 300 participants from 30 countries from all over the world including most eminent researches in the field. Proceedings contain 100 papers on 1500 pages in two volumes and were published by Pineridge Press $[14,15]$. During the Banquet, which was held on September 20, we celebrated the $60^{\text {th }}$ birthday of Prof. Alex C. Scordelis, who was there with his wife. It was a great party with live music, dance and stand-up comedian. After stormy evening, young Rene de Borst (Ph.D. student at that time) conducted after-midnight swimming session. On free afternoon, there was a tennis tournament. Participant played under aliases, the names of contemporary famous tennis players from their countries. As in that time there was no famous 
tennis player from Wales, Prof. Owen played under alias Dylan Thomas (famous Welsh poet), and the other participant were (with their aliases): Zdenek Bazant (Ivan Lendl), William S. Doyle (Kevin Curren), Nenad Bićanić (Nikola Pilić), A.J. Kent (John Lloyd), Stuart S.J. Moy (Buster Mottram), and Kjell Fiskum (Bjorn Borg). The tournament referee was Mrs Judy Doyle, and the winner was Kjell Fiskum from Norway.

There was also, a Pineridge Press Books Exhibition comprising about forty tittles. After the Conference, Prof. Owen donated all exhibited books to the Library of the Faculty of Civil Engineering.

The Conference was a great success in both aspects, scientific and societal interactions.

Two years after the Conference, a book with invited papers of some eminent authors from the Conference was printed [16].

The continuity of this Conference took over conferences under the name EURO-C Computational Modelling of Concrete Structures organized every 3-5 years in different Austrian Ski resorts (1990, Zell am See; 1994, Innsbruck; 1998, Badgastein; 2003, St. Johann im Pongau; 2006, Mayrhofen in Zillertal; 2010, Rohrmoos/Schladming; 2014, St. Anton am Arlberg; 2018, Bad Hofgastein) with ski competitions, under the leadership of Prof. Nenad Bićanić, Prof. Herbert A. Mang, Prof. Rene de Borst, Prof. Gunther Meschke, and later on with Prof. Bernhard Pichler and Prof. Jan G. Rots [17].

\subsection{NLC-1986 DUBROVNIK}

Prof. Owen and Prof. Hinton liked Split and Croatian Coast, and as they were very satisfied with the organization of the ICC-1984 Conference in Split, they came on the idea to organize their $3^{\text {rd }}$ International Conference on Numerical Methods for Non-linear Problems somewhere along the Coast. The choice came upon Dubrovnik. So, Prof. Owen, Prof. Hinton and Prof. Taylor in Swansea and Prof. Damjanić and Pavao Marović, as technical secretary of the Organizing Committee, started with the organization of the Conference.

So, the $3^{\text {rd }}$ International Conference on Numerical Methods for Non-linear Problems (NLC-1986) took place in Dubrovnik, September 15-18, 1986. The Conference was attended by about 200 participants from 25 countries from all over the world including most eminent researches in the field. Its proceedings contain 92 papers on 1306 pages and were published by Pineridge Press [18].

At that time, Prof. Roger Owen together with Prof. Ernest Hinton and Prof. Eugenio Onate was involved in the organization of the $1^{\text {st }}$ Computational Plasticity Conference in Barcelona (April, 6-10, 1987), known later as COMPLAS Conference. In his letter to Prof. Marović, dated October 23, 1986, he stated: "I would like to thank you for the excellent way you organized the Dubrovnik conference - if the Barcelona meeting is half as well organized then there will be no problems." So, the COMPLAS series conferences replaced NLC series conferences.

\subsection{NEC-91 SPLIT/SWANSEA}

After having successfully organized previous two conferences in Split (ICC-1984) and Dubrovnik (NLC-1986), at the end of 1989, Prof. Owen proposed to Prof. Jović to organize next conference somewhere in "Split region" in a suitable conference centre and a nice touristic location to attract delegates. The Organizing Committee was formed including profs. Nenad Bićanić, Ernest Hinton, Roger Owen and Cedric Taylor from Swansea, and profs. Vinko Jović, 
Pavao Marović and Ante Mihanović from Split. The theme of the Conference was chosen to be Nonlinear Engineering Computations. Proposed date was September 16-20, 1991. Due to the contemporary political situation and considering possible simpler communications (without transfers to smaller places with buses or ferries to the islands), the place for the Conference was proposed to be Split. So, at the end we chose Hotel Split in the City of Split.

Organization of the Conference progressed very well; profs. Owen and Bićanić in Swansea received registration forms, payments and papers, while profs. Marović, Mihanović and Jović in Split arranged everything with hotel and accompanying chain of events. Unfortunately, due to the political crisis in the former Yugoslavia, the security situation in Croatia started to be very unstable and unpredictable. We were almost every day in phone contacts. The conclusive meeting was organized in Split at the beginning of May. Professors Owen ad Bićanić came from Swansea, Prof. Damjanić from Ljubljana and profs. Mihanović, Jović and Marović were in Split. In the afternoon on May 8, we had a long meeting considering all aspects of the Conference organization including speculation about political and especially security situation. That afternoon, the final game of the football League Cup was played in Belgrade between Hajduk Split and Red Star Belgrade. As Hajduk won, after dinner we were invited by Mr Vladimir Schoenauer (father of Mr. Miroslav Schoenauer, a contemporary Owen's Ph.D. student) on the Poljud City Stadium to celebrate it. Photo 3 was taken while we were expecting Hajduk football players [19]. Mr Schoenauer requested Hajduk's captain and the scorer of the only goal, Mr. Alen Bokšić, to collect signatures of all players on one ball which was consigned to Prof. Owen. That ball stand for long time in Prof. Owen's office on the honorary place.

Unfortunately, security situation became worse every day. Profs. Bićanić and Marović were in every day phone contacts, and finally on July 10, we decided to dislocate Conference from Split to Swansea. Conference was held in scheduled time in Swansea without Croatian partners.

Proceedings contain 72 papers on 800 pages and were published by Pineridge Press [20].

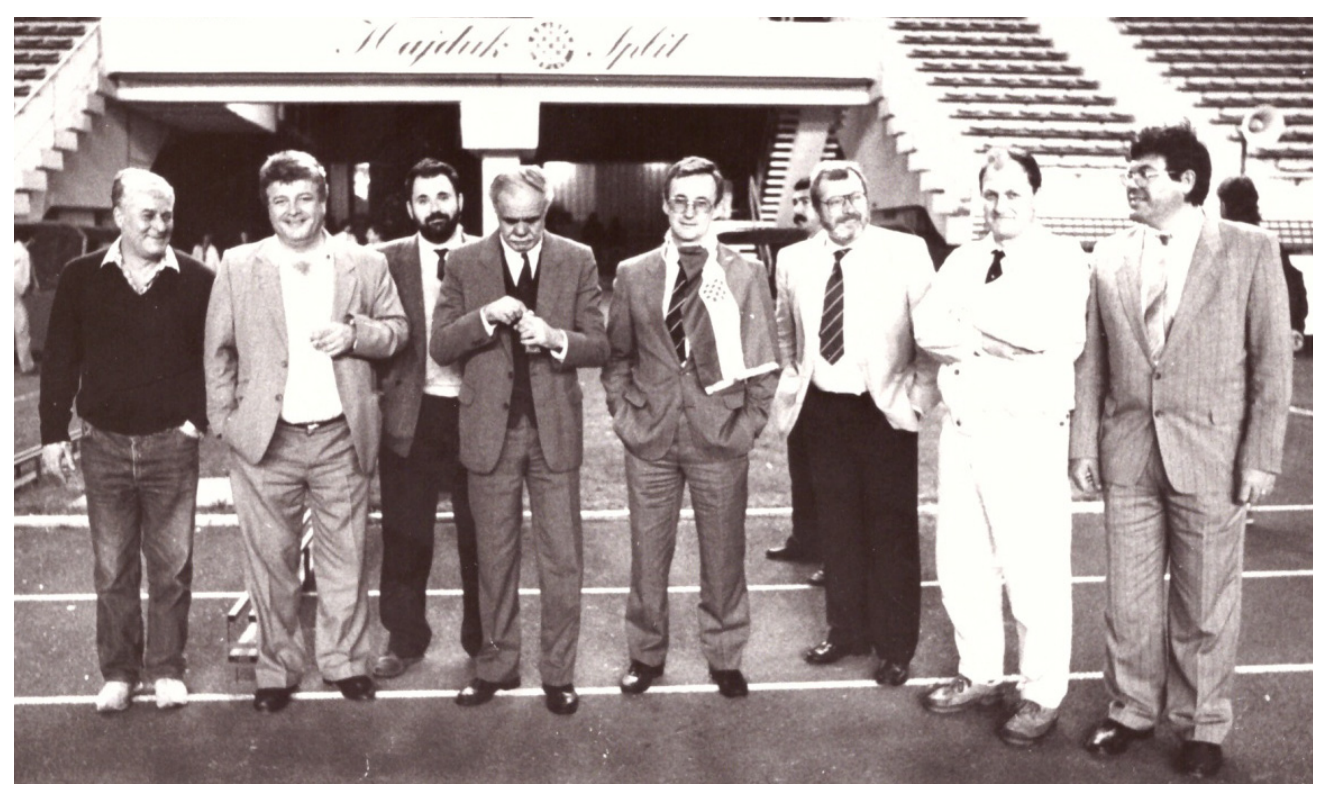

Photo 3 Poljud City Stadium of the FC Hajduk Split: In expectation of the FC Hajduk Split football players after winning National Football Cup, Split, May 8, 1991 (from left: Ivo Bego, ex FC Hajduk Split football player; prof. Vinko Jović; prof. Pavao Marović; Vladimir Schoenauer, ex FC Hajduk Split football player and contemporary Director of the Stadium; prof. Roger Owen; prof. Frano Damjanić; prof. Nenad Bićanić; prof. Ante Mihanović, contemporary Dean of the Faculty of Civil Engineering) (photo: Feđa Klarić) 


\subsection{TEMPUS ACEM PROJECT}

After spending something like a sabbatical year (January 1986 - July 1987) in Swansea at the Department of Civil Engineering of the University College of Swansea (now Swansea University), Prof. Frano Damjanić with altruistic support and help from Prof. Owen started to establish one TEMPUS (Trans-European Mobility Scheme for University Studies) Project under the title Advanced Computational Engineering Modelling (ACEM). Partner Institutions were from eight countries and 15 universities: United Kingdom: University College of Swansea (now Swansea University), Imperial College London, University of Glasgow and University of Southampton; Germany: University of Darmstadt and University of Stuttgart; Italy: Universita degli Studii di Milano and Universita di Padova; Spain: Universitat Politecnica de Catalunya, Barcelona; The Netherlands: Delft University of Technology; France: Universite SophiaAntipolis; Slovenia: Faculty of Architecture, Civil Engineering and Geodesy of University of Ljubljana and Faculty of Mechanical Engineering of the University of Maribor; Croatia: Faculty of Civil Engineering and Faculty of Electrical Engineering, Mechanical Engineering and Naval Architecture of the University of Split and Faculty of Civil Engineering and Faculty of Mining, Geology and Petroleum Engineering of the University of Zagreb.

Prof. Owen should lead this consortium but due to his preoccupation and Prof. Damjanić inability because he was not working at that time in any European Union country, Prof. Bićanić was inaugurated on that position. Prof. Damjanić was coordinator for Croatia (1991-1994) and Slovenia (1991-1996).

Within this TEMPUS-ACEM Project seven short courses were organized in Ljubljana and Maribor (Slovenia) and Zagreb (Croatia) resulting in seven edited Lecture Notes [21-27]. Many young researchers from Croatia and Slovenia spend some time at different consortium institutions throughout Europe gaining appropriate knowledge in their fields from world leading experts in the fields of numerical methods, computational techniques and engineering modelling.

\subsection{THE BRITISH COUNCIL ALIS PROJECTS}

To be in communication and to secure some financial funds for collaboration and mutual visits, we found The British Council Academic Links and Interchange Scheme (ALIS). Prof. Marović proposed and Prof. Owen accepted it, so we proposed to The British Council a project under the title Advanced Nonlinear Modelling of Concrete and Prestressed Concrete Structures (ALIS Project No. 022). Project lasted three years, from April 1, 1996 to March 31, 1999. Every year one person from each institution departed to another institution for up to two weeks. During Prof. Marović's visits to Swansea, he had appreciable discussions with Prof. Owen and his collaborators and research assistants in that time (Đ. Perić (Photo 4), E.A. De Souza Neto, N. Petrinić) about late trends in numerical methods and numerical modelling of different engineering structures, and also, he spent a lot of time in University Library and in the Rockfield Software office in The Innovation Centre. Returning from Swansea, Prof. Marović usually brought a bag full of new books and articles for colleagues in Split obtained with the help of Prof. Owen. During Prof. Owen's visits to Split, beside notable discussions he usually gave the lecture about new trends in the field of computational mechanics and different applications of finite element methods in numerical modelling. Through this project, instead of Prof. Owen, in September 1997, Dr. Nikica Petrinić attended $2^{\text {nd }}$ Congress of Croatian Society of Mechanics which was held in Supetar, and gave a mutual lecture. 


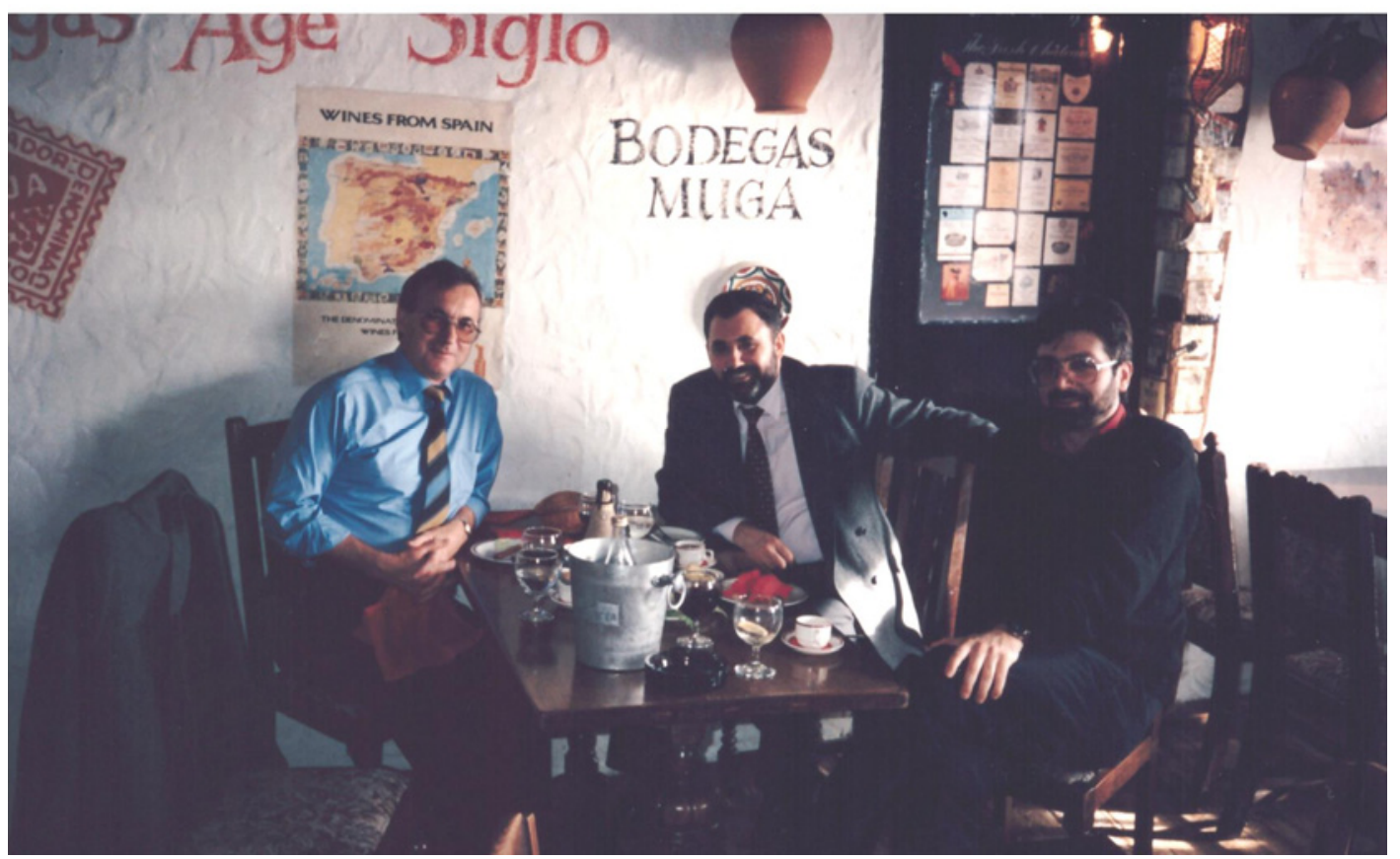

Photo 4 Dinner at restaurant La Braseria in Swansea, February 1998: (from left) Prof. Roger Owen, Prof. Pavao Marović, Dr. Đorđe Perić

Following very good experiences with the first ALIS project, we proposed a continuation of this project and proposed to The British Council a new project under the same title Advanced Nonlinear Modelling of Concrete and Prestressed Concrete Structures (ALIS Project No. 056). Project also lasted three years, from April 1, 2000 to March 31, 2003. During mutual visits we continued with activities from previous project. Prof. Marović again brought a bag full of books and articles obtained with the help of Prof. Owen. Instead of Prof. Owen, in March 2001, Dr. Eduardo De Souza Neto visited Split and gave a mutual lecture.

\subsection{HONORARY MEMBERSHIP OF THE CROATIAN SOCIETY OF MECHANICS}

Professor Roger Owen collaborated with many members of the Croatian Society of Mechanics from early eighty years of the last century but official collaboration with the Croatian Society of Mechanics started from the beginning of its International Congresses, namely from the $1^{\text {st }}$ Congress held in Pula in 1994. He was a member of the Scientific Committee of all nine Congresses giving few Invited Lectures.

So, at the beginning of the 2009 and its $6^{\text {th }}$ International Congress, Prof. Marović, president of the Division Split of the Croatian Society of Mechanics proposed Prof. Owen for honorary membership. General Assembly of the Croatian Society of Mechanics accepted this proposal with some others and elected Prof. Roger Owen to become Honorary Member together with Prof. Satya N. Atluri, Prof. Wilfried B. Kraetzig and Prof. Nenad Bićanić. The solemn ceremony took place at the Congress Dinner of the $6^{\text {th }}$ International Congress of the Croatian Society of Mechanics in Dubrovnik, October 1, 2009. The Charter was consigned by Prof. Jurica Sorić, contemporary President, and Prof. Ivica Smojver contemporary Secretary, of the Croatian Society of Mechanics (Photo 5, left). Next morning, Prof. Owen gave Named Plenary Lecture under the title "Computational strategies for some coupled problems involving particulate media and multi-fracturing solids" (Photo 5, right). 

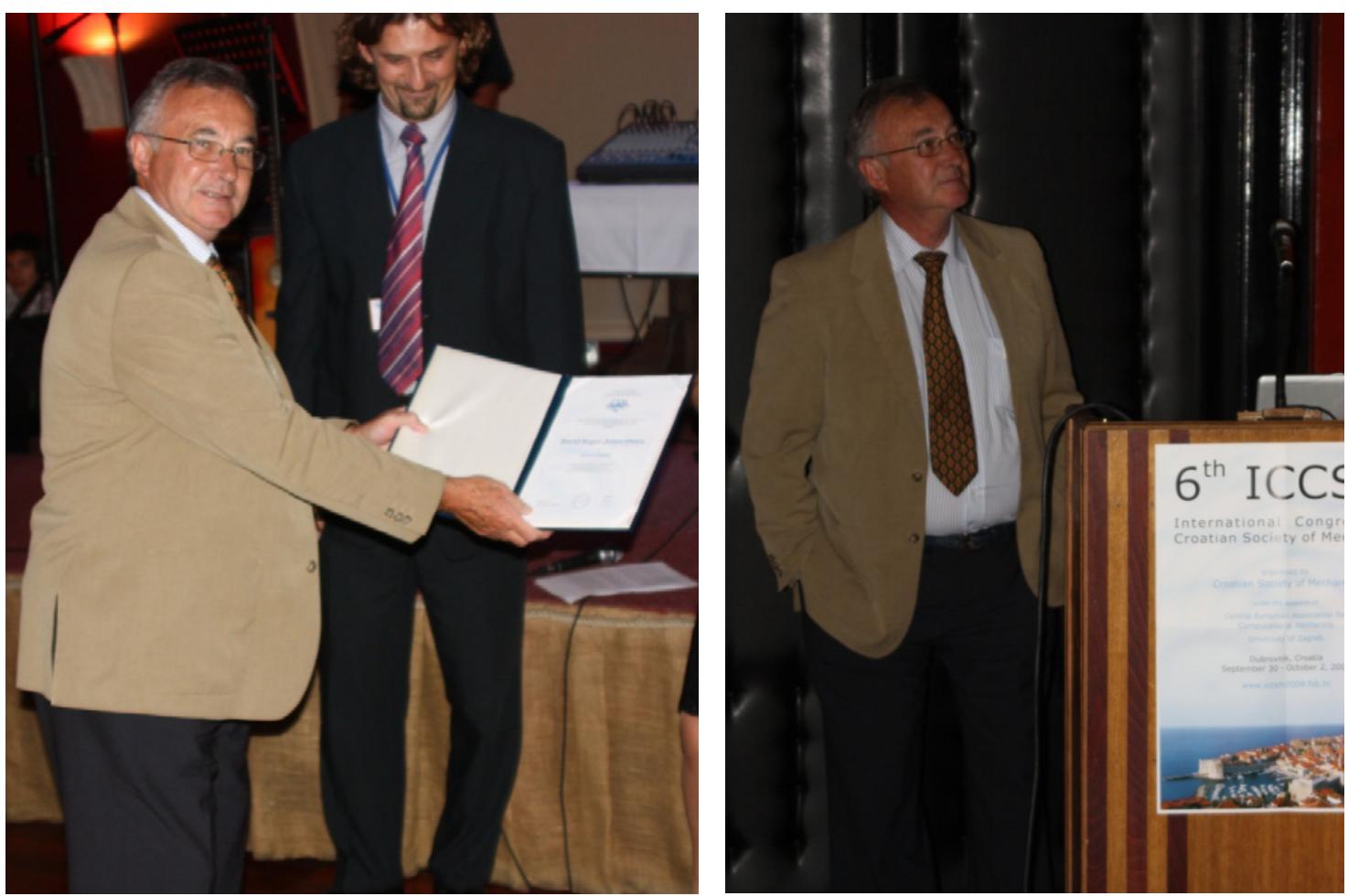

Photo 5 At the $6^{\text {th }}$ International Congress of the Croatian Society of Mechanics, Dubrovnik, September 30 - October 2, 2009 (left: prof. Roger Owen with Charter and prof. Ivica Smojver, October 1, 2009; right: prof. Roger Owen giving Named Plenary Lecture, October 2, 2009

\section{HONORARY DOCTORATE OF THE UNIVERSITY OF SPLIT}

In winter 2014 a group of prof. Owen's friends from the Faculty of Civil Engineering, Architecture and Geodesy proposed to Faculty Management to take up the procedure to award him a Honorary Doctorate of the University of Split. Upon decision of the Faculty Assembly and according to the regulations, the faculty assemblies of the Faculty of Electrical Engineering, Mechanical Engineering and Naval Architecture and University Department of Professional Studies back up the proposal. University Senate on its meeting in May 2015 decides to award Prof. Owen with Honorary Doctorate. As Prof. Owen could not attendant the University Dies Academicus in June 2015, because he was in China in that time, the assignment ceremony was postponed for June 2016, i.e. next University Dies Academicus.

On the solemn meeting of the University Dies Academicus held in June 15, 2016, the assignment of the Honorary Doctorate took place (Photo 6). Photo 7 shows few details from the party after the ceremony. In the evening a group of Prof. Owen's friends and colleagues went on a common dinner (Photo 8). Next day, Prof. Owen gave named lecture under the title "The finite element method: Historical perspective and future prospects" in the Amphitheatre of the Faculty of Civil Engineering, Architecture and Geodesy which was broadcasted by video conference to the Faculty of Civil Engineering in Zagreb, Faculty of Mechanical Engineering and naval Architecture in Zagreb, Faculty of Civil Engineering in Rijeka and Faculty of Civil Engineering in Osijek.

It happens that this was Prof. Owen's the last visit to Split but not to Croatia. In summer 2017 he spend with his family summer vacations in Dubrovnik. 


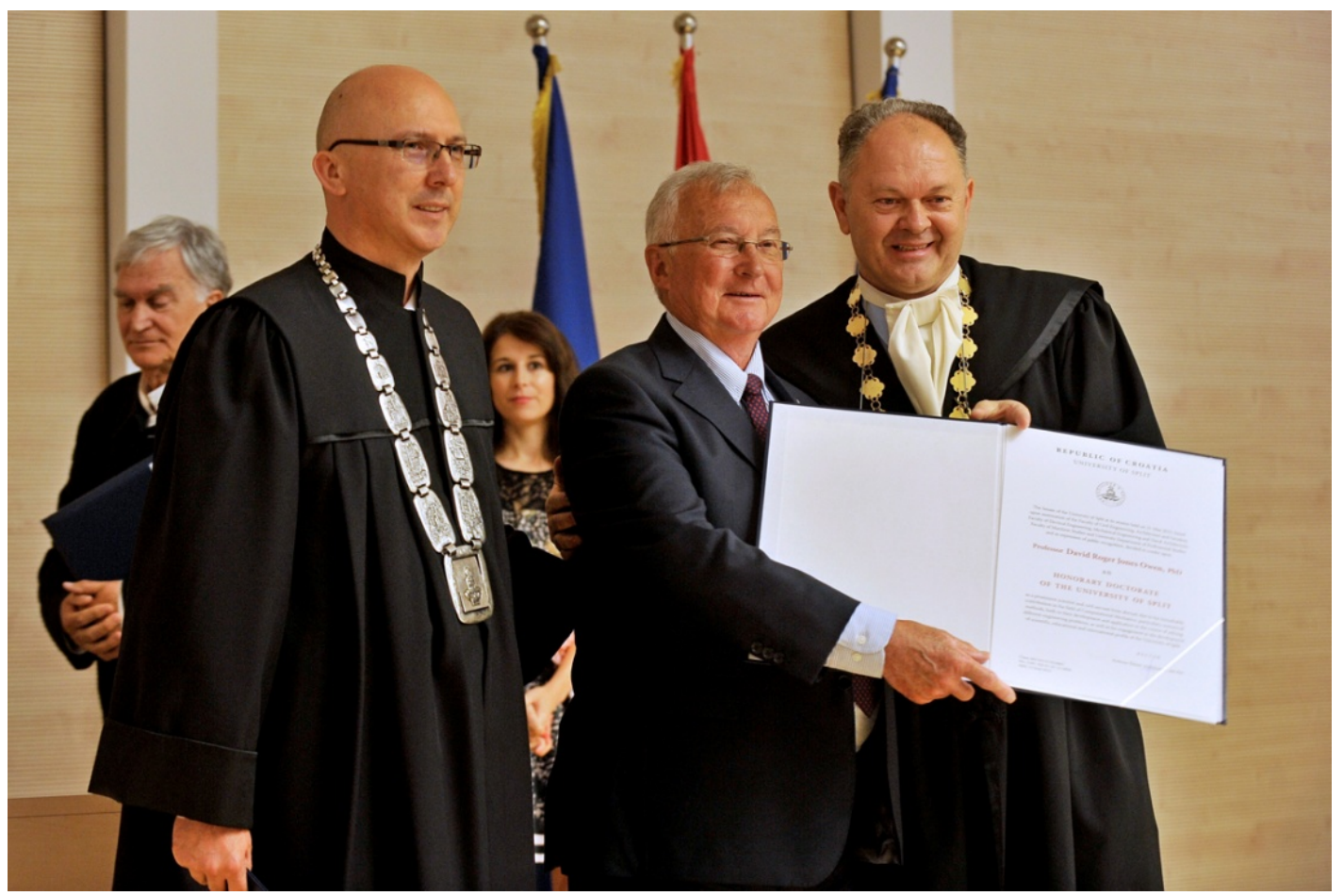

Photo 6 Assignment of the Honorary Doctorate to Prof. Owen (from left: prof. Boris Trogrlić, contemporary Dean of the Faculty of Civil Engineering, Architecture and Geodesy; prof. Roger Owen, prof. Šimun Anđelinović, contemporary Rector of the University of Split)
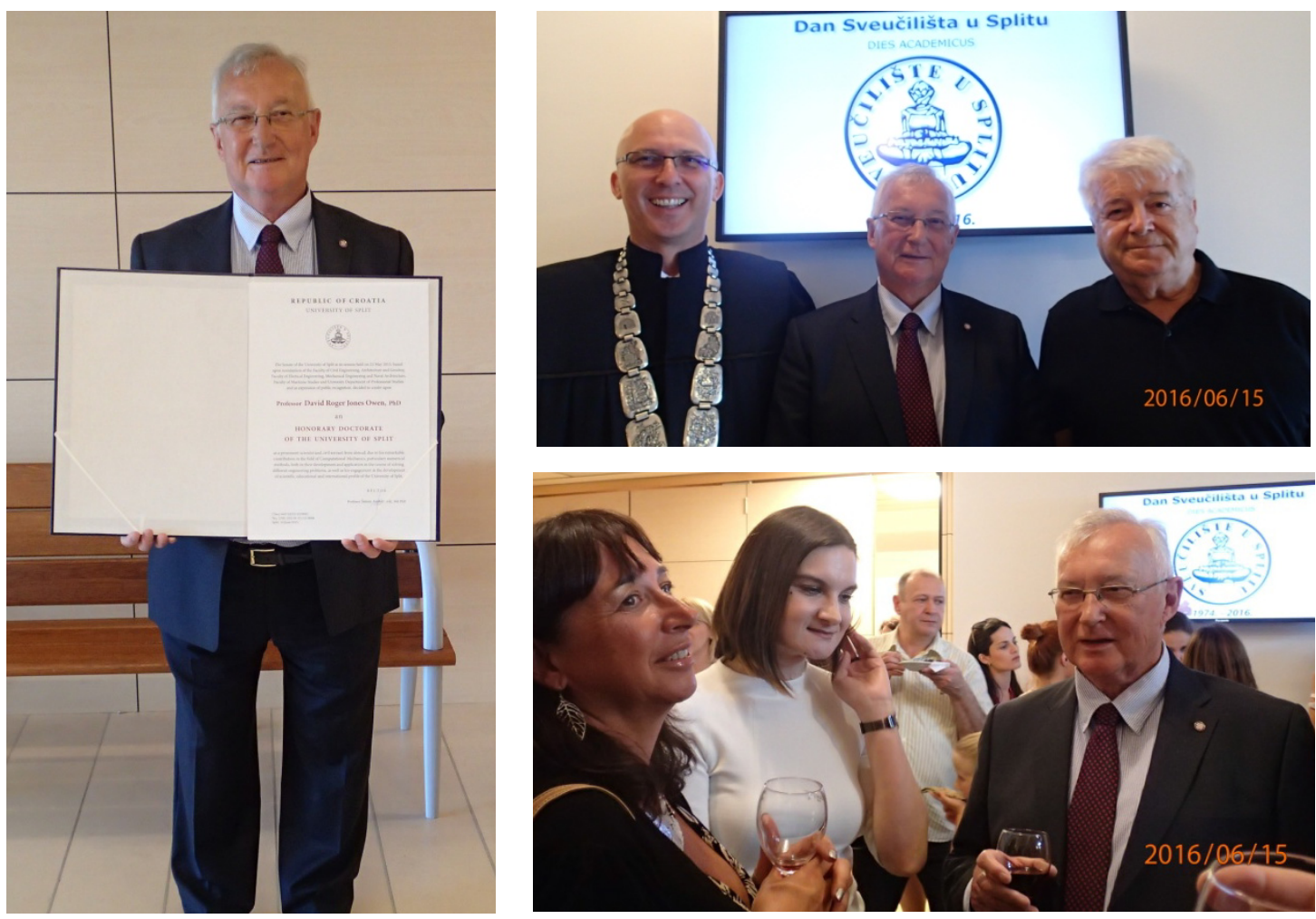

Photo 7 Prof. Roger Owen with Honorary Doctorate Diploma (left); prof. Boris Trogrlić, contemporary Dean of the Faculty of Civil Engineering, Architecture and Geodesy, prof. Roger Owen and prof. Vinko Jović (top); Kathryn Owen, prof. Mirela Galić and prof. Roger Owen (bottom) 


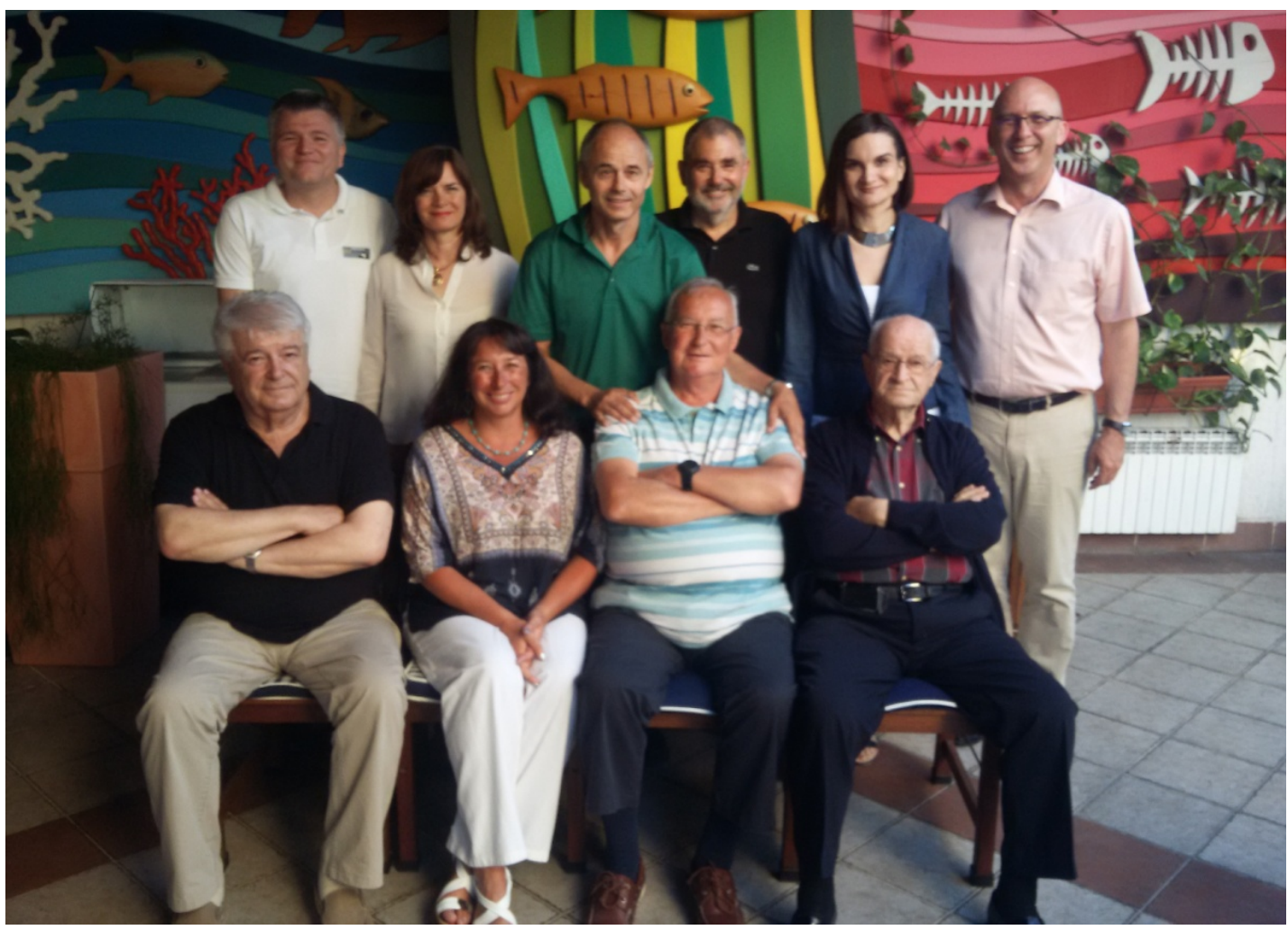

Photo 8 Dinner with friends and colleagues from the University of Split, Faculty of Civil Engineering, Architecture and Geodesy after the assignment ceremony: sitting (from left) Vinko Jović, Katryn Owen, Roger Owen, and Jakša Miličić; standing (from left): Alen Harapin, Željana Nikolić, Ante Munjiza, Pavao Marović, Mirela Galić, and Boris Trogrlić

\section{INSTEAD OF CONCLUSION}

With this article we wanted to refresh memories on Professor Roger Owen, his life axioms and achievements, and especially his connections with the colleagues and friends from the University of Split, Faculty of Civil Engineering, Architecture and Geodesy, as well as some common projects. We all will miss him very much.

Here are few last words of his colleagues and friends from Barcelona and Swansea:

Roger was a person of an extraordinary humanity who knew how to combine a life dedicated to academic work with the enjoyment of the company of his many friends around the world. We have lost a great scientist and a great human being. We will miss him very much [2].

We have lost a great scientist, and a passionate innovator and an outstanding colleague. Professor Owen leaves a massive gap in the fields where he works [4].

What to say at the end? We can only return to the beginning and conclude that the computational modelling community lost eminent scientist and extraordinary friend.

Rest in peace eternally in your adorable Welsh country. Iechyd da. 


\section{REFERENCES}

[1] D.R.J. Owen, My Curriculum Vitae, Unpublished materials, Swansea/Split, 2015.

[2] E. Onate, Death of Professor Roger Owen, CIMNE web pages, Published 15/01/2020, https://cimne.com/vnews/10930/death-of-professor-roger-owen (accessed: April 08, 2020)

[3] P. Marović, In memoriam - prof. Roger Owen, University of Split, Faculty of Civil Engineering, Architecture and Geodesy web pages, Published 20/01/2020, http://gradst.unist.hr/novosti/articletype/articleview/articleid/4060/in-memoriam-prof-roger-owen

[4] Anonymous, Professor Roger Owen Obituary, Swansea University, 2020. https://www. swansea.ac.uk/engineering/engineering-news/professor-owen/ (accessed: May 01, 2020)

[5] D.R.J. Owen, Continuum Theory of Dislocations, Ph.D. Thesis, Northwestern University, Evanston, 1967.

[6] E. Hinton, D.R.J. Owen, Finite Element Programming, Academic Press, London, 1977.

[7] E. Hinton, D.R.J. Owen, An Introduction to Finite Element Computations, Pineridge Press, Swansea, 1979.

[8] D.R.J. Owen, E. Hinton, A Simple Guide to Finite Elements, Pineridge Press, Swansea, 1980.

[9] D.R.J. Owen, E. Hinton, Finite Elements in Plasticity: Theory and Practice, Pineridge Press, Swansea, 1980.

[10] D.R.J. Owen, A.J. Fawkes, Engineering Fracture Mechanics: Numerical Methods and Applications, Pineridge Press, Swansea, 1983.

[11] E. Hinton, D.R.J. Owen, Finite Element Software for Plates and Shells, Pineridge Press, Swansea, 1984.

[12] E.A. de Souza Neto, D. Peric, D.R.J. Owen, Computational Methods for Plasticity: Theory and Applications, John Wiley and Sons, Chichester, 2008.

https://doi.org/10.1002/9780470694626

[13] F.B. Damjanić, Reinforced Concrete Failure Prediction under both Static and Transient Conditions, Ph.D. Thesis, C/Ph/71/83, University of Wales, Swansea, 1983.

[14] Proceedings of the International Conference on Computer Aided Analysis and Design of Concrete Structures, Part I, Eds.: F. Damjanić, E. Hinton, D.R.J. Owen, N. Bićanić, V. Simović, Split, September 17-21, 1984, Pineridge Press, Swansea, 1984.

[15] Proceedings of the International Conference on Computer Aided Analysis and Design of Concrete Structures, Part II, Eds.: F. Damjanić, E. Hinton, D.R.J. Owen, N. Bićanić, V. Simović, Split, September 17-21, 1984, Pineridge Press, Swansea, 1984.

[16] Computational Modelling of Reinforced Concrete Structures, Eds.: E. Hinton, D.R.J. Owen, Pineridge Press, Swansea, 1986.

[17] https://euro-c.tuwien.ac.at/home/ (accessed: May 12, 2020)

[18] Proceedings of the 3rd International Conference on Numerical Methods for Non-linear Problems, Eds.: C. Taylor, D.R.J. Owen, E. Hinton, F.B. Damjanić, Dubrovnik, September 15-18, 1986, Pineridge Press, Swansea. 1986. 
[19] P. Marović, Story about one photo - Contribution to the history of Croatian Society of Mechanics, In: Proceeding of the $8^{\text {th }}$ Annual Meeting of the Croatian Society of Mechanics, eds.: D. Penava, I. Guljaš and M. Bošnjak-Klečina, Osijek, July 7-8, 2017, HDM, Osijek, pp. 149-156, 2017. (in Croatian)

[20] Proceedings of the $4^{\text {th }}$ International Conference on Nonlinear Engineering Computations, Eds.: N. Bićanić, P. Marović, D.R.J. Owen, V. Jović, A. Mihanović, Split/Swansea, September 16-19, 1991. Pineridge Press, Swansea, 1991.

[21] N. Bićanić, F.B. Damjanić (eds.): Lecture Notes on Nonlinear Engineering Computations, $1^{\text {st }}$ Short Course Lecture Notes, TEMPUS ACEM, Ljubljana, May 13-15, 1992, IKPIR-FAGG, Ljubljana, 1992.

[22] N. Bićanić, F.B. Damjanić, A. Szavits-Nossan (eds.): Lecture Notes on Geometrically Nonlinear Problems, $2^{\text {nd }}$ Short Course Lecture Notes, TEMPUS ACEM, Zagreb, June 2829,1992, Faculty of Civil Engineering, Zagreb, 1992.

[23] N. Bićanić, F.B. Damjanić, P. Škerget (eds.): Lecture Notes on Theoretical Background and Practical Applications of Advanced Computational Mechanics Packages, $3^{\text {rd }}$ Short Course Lecture Notes, TEMPUS ACEM, Maribor, August 29-30, 1992, Faculty of Mechanical Engineering, Maribor, 1992.

[24] T. Rodič, F.B. Damjanić, N. Bićanić (eds.): Lecture Notes on Computational Methods in Nonlinear Mechanics, $5^{\text {th }}$ Short Course Lecture Notes, TEMPUS ACEM, Ljubljana, October, 1993.

[25] T. Rodič, F.B. Damjanić, N. Bićanić (eds.): Lecture Notes on Process Simulation in Industrial Metal Forming, $6^{\text {th }}$ Short Course Lecture Notes, TEMPUS ACEM, Ljubljana, October, 1993.

[26] T. Rodič, F.B. Damjanić, N. Bićanić (eds.): Lecture Notes on Numerical Simulation of Metal Forming Operations, $7^{\text {th }}$ Short Course Lecture Notes, TEMPUS ACEM, Ljubljana, October, 1993.

[27] F.B. Damjanić, P. Škerget, N. Bićanić (eds.): Lecture Notes on Computational Fluid Dynamics, $8^{\text {th }}$ Short Course Lecture Notes, TEMPUS ACEM, Ljubljana, May, 1994. 